was justifiable to install something of lesser quality simply because it was cheaper. The court also discounted an argument that a digital organ was easier to play by a non-expert organist. Although the case was borderline, the following factors resulted in the court concluding that it was appropriate to authorise the installation of a digital organ. First, the PCC had given serious consideration to the issues relevant to the type of instrument they wished to install. This was a necessary, but not sufficient, condition. Second, and more significantly, installing a pipe organ would have an adverse impact on space and openness, which were significant features of the reconstructed church. The intention of creating an open and flexible building would be hindered if a pipe organ were installed and the parish would not enjoy the full benefits that would otherwise flow from the reconstruction. On balance, enabling the parish to enjoy those benefits was judged to be a sufficient reason for permitting the installation of a digital organ. As to the proposal for a moveable font (which was supported by the archdeacon), the chancellor held that the same arguments about the flexible use of space in the new church applied equally to the question of whether the font should be fixed or moveable. There were cases where it was appropriate for the font to be located away from the main entrance to the church, and a moveable font was not necessarily impermissible. However, a moveable font must be substantial, both physically and symbolically. A faculty for the introduction of a moveable font would be granted subject to conditions as to its design, scale, appearance and materials and as to securing its suitable location in the church when not in use. [Alexander McGregor]

doi:10.1017/So956618X12000518

\title{
$\mathrm{R}$ (on the application of National Secular Society and Bone) $\mathrm{v}$ Bideford Town Council
}

Administrative Court: Ouseley J, February 2012

Council meeting - prayers - discrimination

The application by a former Bideford councillor, supported by the National Secular Society, challenged the practice of public prayers at the start of council meetings on the basis that this discriminated indirectly against councillors with atheist or non-Christian beliefs and was ultra vires the Local Government Act 1972. It was held that the holding of prayers did not discriminate either directly or indirectly against those of non-Christian beliefs as they could absent themselves either by physically leaving the council chamber or by not taking part in them. However, it was also held that there was no power, explicit or implicit, to hold prayers as part of the council meeting. Bideford Council's votes to hold prayers were therefore void as being ultra vires council 
powers. This did not prevent councillors praying together before the meeting but not as part of the meeting. [Catherine Shelley]

doi:10.1017/So956618X1200052X

\section{Sharpe v Worcester Diocesan Board of Finance and anor} Employment Tribunal: Employment Judge McCarry, February 2012 Employment status - incumbent - unfair dismissal

Mr Sharpe, a former freehold incumbent in the Diocese of Worcester, sued the Diocesan Board of Finance (DBF) and the bishop in his corporate capacity, principally alleging constructive and unfair dismissal. The tribunal distinguished the recent judgment of the Court of Appeal in President of the Methodist Conference $v$ Preston [2011] EWCA Civ 1581, because in that case the judge had held that the only possible relationship between the parties had been a contractual one. $\mathrm{Mr}$ Sharpe's position as an Anglican rector with freehold was different, however. His relationships with the Church and the bishop were defined by ecclesiastical law; and issues such as hours of work and holidays were left - non-contractually - to his discretion, subject only to guidelines as to its exercise. There was no basis for finding that he had a legal relationship with the DBF, since the DBF was not party to his appointment, it received no services from him and he carried out none on its behalf, and it did not supervise him. Nor was there a contract between $\mathrm{Mr}$ Sharpe and the bishop. It was the DBF, not the bishop, that paid his stipend, and the bishop's supervisory powers were limited and defined by law rather than by any consensual arrangement. The situation exhibited a lack of supervision and control and included no element of personal service. Mr Sharpe served the DBF and the bishop only in the general sense of assisting the Church's mission. A general duty to obey the law of the Church was not the same as entering into a contract of service. In short, there was neither a contract of employment nor a contract of service and the claim was dismissed. [Frank Cranmer]

doi:10.1017/So956618X12000531

\section{Bull and Bull v Hall and Preddy}

Court of Appeal Civil Division: Morritt Ch, Hooper and Rafferty LJJ, February 2012

Discrimination - hotel - double room - sexual orientation - religious belief

The appellants, Christian hotel proprietors who believed that sexual relations should only take place within monogamous heterosexual marriage, appealed 